\author{
Lyudmyla Niemets \\ DSc (Geography), Professor, Head of the Department of Human Geography and Regional Studies \\ e-mail: ludmila.nemets@karazin.ua, ORCID ID: https://orcid.org/0000-0001-9943-384X \\ Maryna Lohvynova \\ PhD Student of the Department of Human Geography and Regional Studies \\ e-mail: logvinova_mari94@ukr.net, ORCID ID: https://orcid.org/0000-0003-3190-710X \\ Olha Suptelo \\ PhD Student of the Department of Human Geography and Regional Studies \\ e-mail: syptelo@gmail.com, ORCID ID: https://orcid.org/0000-0003-2901-8565 \\ V.N. Karazin Kharkiv National University, Svobody Sq., 4, Kharkiv, 61022, Ukraine

\section{SOCIOLOGICAL METHODS IN HUMAN-GEOGRAPHIC RESEARCHES: FEATURES OF APPLICATION}

Human geography, which is an integral branch of contemporary geographical science, relies on a broad methodological basis, using both the general geographical methodological apparatus and the methodological apparatus of related and related sciences. However, taking into account the specifics of the object-subject field of human geography, it is necessary to improve the methodological apparatus, going beyond the use of methods inherent only in geographical science. The anthropogenic factor becomes dominant in all negative changes in the interaction of the "society-human-nature" system. There is a need to replenish the methodological apparatus of human geography through the use of methods of related sciences, in particular, sociology. Sociological methods operate with large amounts of data and can be applied at various stages of socio-geographical research: at the stage of collecting information, its processing and interpretation. Among Ukrainian scientists, human geographers, for now, the use of sociological methods of collecting and processing information is more ignored, unlike foreign scientists.

The use of traditional socio-geographical methods and ignoring the methods of related sciences indicate the need for a thorough review of the methodological and methodological foundations of socio-geographical research. This is required by the complexity of the global processes of socio-economic development of modern civilization as a single global socio-geographic system of the planet. At the stage of collecting socio-geographical information, it is important to use sociological methods of collecting information that are indispensable for the study of those features of geographical systems that are not covered by official statistics, as well as for the study of factors of processes and phenomena at the individual and group levels.

Sociological research methods have a branched structure, in which they are distinguished as general scientific and special sociological research methods. Sociological methods of data collection can be used in socio-geographical studies, the choice of which depends on the type of goals, objectives, features of the object of study, the material capabilities of the researcher and the capabilities of the toolkit. Sociological methods for collecting information are divided into 5 main classes: survey, analysis of documents, experiment, observation and testing. searches.

Keywords: sociological methods, methods of collecting information, survey, questioning, interviews, human-geography re-

Людмила Нємець, Марина Логвинова, Ольга Суптело. СОЦІОЛОГІЧН МЕТОДИ В СУСПІЛЬНОГЕОГРАФІЧНИХ ДОСЛЦЖЕННЯХ. ОСОБЛИВОСТІ ЗАСТОСУВАННЯ

Мета дослідження - аналіз існуючих соціологічних методів збору інформації та їх адаптація до суспільногеографічних досліджень. Враховуючи майже повне ігнорування соціологічних методів збору інформації з боку провідних українських суспільних географів, надання переваги офіційним статистичним ресурсам, які не дають конкретної відповіді про причинно-наслідкові зв'язки виникнення та розвитку суспільно-географічних процесів і явищ, аналізуючи відповідний зарубіжний досвід таких досліджень, наголошуємо на необхідності проведення досліджень з урахуванням методичного апарату соціологічних дисциплін. Оскільки суспільні процеси і явища складні, багатоваріантні, форми їх прояву різноманітні, то можливість об'єктивного вивчення суспільних явищ і отримання відповідних результатів в значній мірі обумовлені достовірністю і якістю зібраного матеріалу. У суспільно-географічних дослідженнях можуть використовуватись соціологічні методи збору даних, вибір яких залежить від типу, цілей, завдань, особливостей об'єкту дослідження, матеріальних можливостей дослідника та можливостей інструментарію.

Авторами розглянуто та вдосконалено класифікації соціологічних методів збору інформації, проаналізовано 5 основних класів соціологічних методів збору інформації: опитування, аналіз документів, експеримент, спостереження та тестування. Розглянуто конкретне застосування соціологічних методів збору інформації при вивченні внутрішньо переміщених осіб в Україні, що дозволяє вивчити окремі психологічні особливості переселенця або групи переселенців, їх взаємодію 3 іншими ВПО та місцевим населенням, проблеми, які виникають перед внутрішньо переміщеними особами та заважають успішній інтеграції у приймаючі громади тощо, тобто ті характеристики, які неможливо виділити за допомогою офіційної статистики. Авторами розроблена анкета для проведення структурованого інтерв’ю з внутрішньо переміщеними особами. Наголошено на необхідності більш широкого використання соціологічних методів збору інформації у суспільногеографічних дослідженнях, це дозволяє підвищити гуманітарно-соціальну складову дослідження.

Ключові слова: соціологічні методи, методи збору даних, опитування, анкетування, інтерв'ю, суспільно-географічні дослідження.

(C) Niemets L., Lohvynova M., Suptelo O., 2019 
Людмила Немеи, Марина Логвиова, Ольга Суптело. СОЦИОЛОГИЧЕСКИЕ МЕТОДЫ В ОБЩЕСТВЕННОГЕОГРАФИЧЕСКИХ ИССЛЕДОВАНИЯХ. ОСОБЕННОСТИ ПРИМЕНЕНИЯ

Цель исследования - анализ существующих социологических методов сбора информации и их адаптация к общественно-географическим исследованиям. Учитывая почти полное игнорирование социологических методов сбора информации со стороны ведущих украинских общественных географов, предпочтения официальным статистическим ресурсам, которые не дают конкретного ответа о причинно-следственных связях возникновения и развития общественногеографических процессов и явлений, анализируя соответствующий зарубежный опыт таких исследований, отмечаем необходимость проведения исследований с учетом методического аппарата социологических дисциплин. Поскольку общественные процессы и явления сложные, многовариантные, формы их проявления разнообразны, то возможность объективного изучения общественных явлений и получение соответствующих результатов в значительной степени обусловлены достоверностью и качеством собранного материала. В общественно-географических исследованиях могут использоваться социологические методы сбора данных, выбор которых зависит от типа, целей, задач, особенностей объекта исследования, материальных возможностей исследователя и возможностей инструментария.

Авторами рассмотрены и усовершенствованы классификации социологических методов сбора информации, проанализированы 5 основных классов социологических методов сбора информации: опрос, анализ документов, эксперимент, наблюдение и тестирование. Рассмотрено конкретное применение социологических методов сбора информации при изучении внутренне перемещенных лиц в Украине, что позволяет изучить отдельные психологические особенности переселенца или группы переселенцев, их взаимодействие с другими ВПЛ и местным населением, проблемы, которые возникают перед внутренне перемещенными лицами и мешают успешной интеграции в принимающие общества и тому подобное, то есть те характеристики, которые невозможно выделить при помощи официальной статистики. Авторами разработана анкета для проведения структурированного интервью с внутренне перемещенными лицами. Отмечена необходимость более широкого использования социологических методов сбора информации в общественно-географических исследованиях, это позволяет повысить гуманитарно-социальную составляющую исследования.

Ключевые слова: социологические методы, методы сбора информации, опрос, анкетирование, интервью, общественно-географические исследования.

Formulation of the problem. Human geography, which is an integral part of contemporary geographic science, relies on a broad methodological base, using both the general geographic methodological apparatus and the methodological apparatus of related and related sciences. In this context, it is interesting to note that human geography has a humanitarian orientation, while related humanities, such as sociology and anthropology, do not have such widespread use. This, of course, is associated with the strong influence of materialist orientations in geography, which hindered the development of interpretive traditions in this area [32]. However, in view of the specifics of the object-subject domain of human geography, the improvement of the methodological apparatus is necessary, going beyond the limits of the use of methods that are inherent only in geographic science.

The properties of social, socio-geographical systems and society as a whole, as an object of study of human geography, are characterized by dynamic features, periodic phase transitions, changes in the priorities of society, crisis phenomena, a high level of social mobility, the presence of structural components that provoke contradictions and create conflict situations. These systems are influenced by external and internal factors that bring additional disturbances into society, therefore it is necessary to take into account the abovementioned features of modern society. This requires the search for new approaches and methods, their integrated application in human geography researches. The relevance of this scientific article is also due to the change in the vector of research of social geography from the definition of territorial features of development, with an emphasis not only on the economic potential, but also on the identification of various properties of society, and its impact on the relevant territory. After all, it is the anthropogenic factor that becomes dominant in all negative changes in the interaction of the "societyhuman-nature" system. There is a need to replenish the methodological apparatus of human geography through the use of methods of related sciences, in particular, sociology. Sociological methods operate with large amounts of data and can be applied at various stages of human geography researches: at the stage of collecting information, its processing and interpretation. This study reveals the peculiarities of using sociological methods of collecting information in human geography researches.

Analysis of previous research and publications. Human geography is a complex science that has the goal of the fullest possible study of society, which is open and dynamic, therefore the set of methods used by it is constantly transformed. So in 1985, Eliot Hurst noted that human geography is more a sociological science than a geographical and its methodological apparatus should already be integrated with a sociological [29]. According to Ley, research using sociological methods is aimed at understanding the actions and intentions of people, the content of events and opportunities they face in their everyday lives [30]. At the same time, David Harvey, who is actively exploring cities and social justice, emphasizes that apart from identifying social processes, their causes and patterns, the spatial component should not be neglected. This he called "geographical imagination" [28].

At the same time, Robin Flowerdew and David Martin, in the book Methods in Human Geography (2005), emphasize that human geography is a symbiosis in the study of the properties of society, of people's thoughts, of social relations and of the spatial component ("geographical imagination"). The authors argue that pure sociological or geographic research does not make sense. Since society at this stage of development is a key factor in the development of the territory, then an analysis of public opinion is important, while it is inadmissible to ignore the spatial component [Methods in human geography]. J. Baxter and J. Eyles, considering qualitative socio-geographical research, also emphasize the necessity of using a complex of methods of different 
sciences, but the use of these methods should be wellgrounded, which is especially relevant to sociological methods at the stage of information gathering. The authors suggest an example of a deep interview, emphasizing that the choice of respondents should be careful [25].

L. Philip, considering the potential of the approach to using different methods in human geography, emphasizes sociological methods in social studies, which have so far been neglected in geographic literature, emphasizing the need to combine qualitative and quantitative methods [31].

G. Clark emphasizes that the main difference between economists and geographers is the value that the former provides to stylized facts, and the very different meaning that the latter provide to the diversity of economic life. Offering an alternative to the theory of stylized facts, noting the relationship between theory and empiricism, the author notes that human geographers should take the point of view of the studied subjects and objects that are theoretically justified. Regarding data used in research, Clark notes that collecting data, the researcher should take the position of a strict sociologist [26].

In the writings of Ukrainian scholars, polarization of thought about the system of methods of human geography is clearly traceable. According to O. Shablii, the latest period in the development of human geography is increasingly affected by sociologization and humanization [24], and therefore, the research methods used by it are borrowed and adapted from sociological and other humanities. However, the scientist also emphasizes the use of economic methods, in particular: the balance method, industry and interbranch method, the method of energy cycles, the method of economic and socio-economic zoning, and other derivative methods of economics.

A. Topchiev shares the views of O. Shablii on the transformation of the system of methods of human geography. The researcher draws attention to the fact that the present stage of development of sociogeographical science differs from previous massive applications of geoinformation technologies and increased integration of geographic sciences with sociological and economic sciences [21]. However, among the methods used by contemporary human geography, the emphasis has also been shifted to the economic component, and among the list of sources of information, the focus is on statistical information obtained from the departments of statistics and governing structures [21].

The researcher of the features of spatial analysis in human geography $\mathrm{K}$. Niemets draws attention to the inseparability of the spatial component in sociogeographical research. At the same time, the scientist attaches great importance to social processes; however, $K$. Niemets names the mathematical and statistical methods as the main methods of their research, ignoring the social component [13].

In general, it can be concluded that among Ukrainian human geographers, so far, the use of sociological methods of collecting and processing information is more ignored, unlike foreign scientists.
Qualitative methods in human geography, in particular sociological, to a certain extent, are presented in the book Social Geography, edited by L. Niemets and K. Mezentsev in 2019 [14]. The authors emphasize the complex structure of contemporary human geography, which in turn leads to a complication of the system of methods that it uses. In general, the methods used in human geography are divided by authors into quantitative and qualitative. The first group includes all methods that provide for the analysis of empirical studies with significant arrays of statistical data. And to the group of qualitative methods - those aimed at the analysis of non-numerical data, and which can provide a subjective characteristic of socio-geographical objects. The basis of qualitative methods in this case are sociological and general scientific methods adapted to the needs of human geography. For example, there are such methods as: interviews, interviews, focus groups, the method of included observation, document analysis [14].

An example of the practical use of sociological methods in human geography is the work of M. Myrosh "Methodology of socio-geographical study of political activity of the population of the region". In it, sociological methods, such as surveys and questionnaires, are used to analyze electoral preferences [10].

I. Savchenko, O. Shevchuk believe that sociological methods are mandatory in the study of territorialpolitical systems, because they prefer such a method as content analysis. The essence of this technique is to find information by specific words, phrases (so-called "semantic units"), which enables, first of all, to reveal the fullness of the space by the object of the search [19].

A certain attempt to generalize the methodology of geographic research is made by $M$. Saliuk, who considers the methodology of studying documents and sociological polls of the population as sources of geographic information, quantitative methods in geography, etc. The author examines the notion of sociological research, the stage of the process of sociological survey and develops a questionnaire for a sociological survey [20].

Identification of previously unsettled parts of the general problem. The use of traditional sociogeographical methods and the ignoring of the methods of related sciences indicate the need for a thorough review of the methodological foundations of socio-geographical research. This is necessary, given the complexity of global processes of socio-economic development of modern civilization as the only global sociogeosystem of the planet [15]. Manifestations of aggression, terrorism, and other threatening processes in different parts of the world require the consideration and study of social aspects, negative features of the global society as a whole and its individual components. Identifying the features of society at all its hierarchical levels from local to global is an extraordinary task of human geography. Human becomes the main force and the main cause of most of the disasters on the planetIt is necessary to combine the achievements of sociology and human geography to study these issues and find ways to solve global problems of humanity. 
Human geography, especially its social field, has the potential and should explore such new challenges to science. This requires revision of theoretical and methodological principles of human geography. Its must be based on the generally accepted theoretical and methodological basis of human geography, but taking into account the methodological techniques of related sciences. Therefore, an important task is to create a toolkit for research: specific methods and algorithms; systems of principles, methods and indicators; forecasting tools. At the stage of collecting sociogeographical information, it is important to use sociological methods for collecting information that are indispensable for the study of those features of geographical systems that are not covered by official statistics, as well as for the study of factors of processes and phenomena at the individual and group levels. Therefore, we consider it expedient to create a systematization of sociological methods for collecting information, outline the advantages of using these methods in socio-geographical research, and also adapt these methods in accordance with the object of research.

Formulating the purpose of the article. The purpose of the study is to analyze existing sociological methods of information gathering and their adaptation and use in human geography researches. Achieving the purpose of the study contributes to the formulation of research questions: what is the place of sociological methods in the methodological apparatus of social geography? Why is it necessary to use sociological methods in human geography and what exactly? The object of research is the sociological methods of collecting socio-geographical information. The subject of the study is the peculiarities of the use of sociological methods for gathering information in human geography.

Presentation of the main research material. It is common knowledge that the methodology is understood as a set of principles, approaches that allow the realization of research intentions. The term "methodology" is derived from the Greek methodos - a way of knowing and logos - a teaching, a word. The methodology has three main interpretations: methodology is a science of the way of knowledge; methodology - a set of general principles, provisions and methods that form the basis of this science; methodology - a set of methods of research used in this science [11].

The main element of the methodology is the research methods (fig. 1). The method of research is a peculiar architecture of science, the main purpose of which is to obtain reliable knowledge, using the tool of knowledge and reality [6].

Sociological research methods have a branched structure, in which they are distinguished as general scientific and special sociological research methods. In sociogeographical research sociological methods of data collection can be used, the choice of which depends on the type, goals, tasks, features of the object of research, material resources of the researcher and the capabilities of the toolkit [3].

Experience shows that the methodological problems of using sociological methods in human geography are due to their peculiarity of application, the need to use theoretical concepts of sociology, means of analysis and synthesis; compulsory conceptualization of empirical data and conclusions.

Methods of collecting sociological information of a specific human geography study serve as an instrument that ensures the obtaining of primary data in the course of this study, while taking into account not only the research objectives and objectives, but also the subjectobject area of research, which sometimes impose restrictions on the way of obtaining information etc. (tab. 1). Sociological methods for collecting information are divided into 5 main classes: surveys, document analysis, experiment, observation and testing [18].

Observation - a method of collecting sociological information, in which there is a direct visual or auditory perception of real events and their registration. Observation may be occasional, systematic, field, laboratory, included, unincluded, controlled, uncontrolled, structured, unstructured [3]. The most complete method can be used in the study of public spaces of cities. For example, observing urban public spaces can provide an opportunity to determine the saturation of public spaces with objects necessary for communication, leisure, recreation and entertainment; characterize visitors of the public space by age, gender, social status; analyze the intensity of use and segmentation of public spaces in relation to different types of activities.

Document analysis - a way to obtain information through access to documents. The methods of document analysis are extremely diverse, however, two basic types of analysis are quite clearly distinguished among them: traditional and formalized (quantitative), complementing each other [1]. Traditional (classical) analysis is a chain of logical operations aimed at interpreting data in accordance with the purpose of the study. This analysis is directed deep into the document, to the full "exhaustion" of its contents. The main drawback of this analysis is the subjectivity of the approach of the researcher.

Qualitative analysis of documents is a prerequisite for all quantitative operations aimed at releasing a researcher of subjectivity. The main procedures of content analysis are related to the transfer of quality information into the language of numbers [18].

Testing - a method of measuring and assessing the psychological qualities and states of the subject. Testing can be group (sociometric), individual, direct, projected. [3]. Sociometry - the theory of measuring interpersonal relationships, the method of studying intra-group relationships and hierarchies in small groups. A modified version of sociometry can also be used to study larger groups, for example, organizations or groups of the population. Sociometry is an applied method both in psychology (social psychology, psychotherapy), and in sociology. A significant disadvantage of sociometry is that it can only be investigated by already established groups. To create new teams you need to use other methods.

Another method of data collection is an experiment - a method of knowing social reality, through which the phenomena of reality are investigated in controlled conditions [3]. 


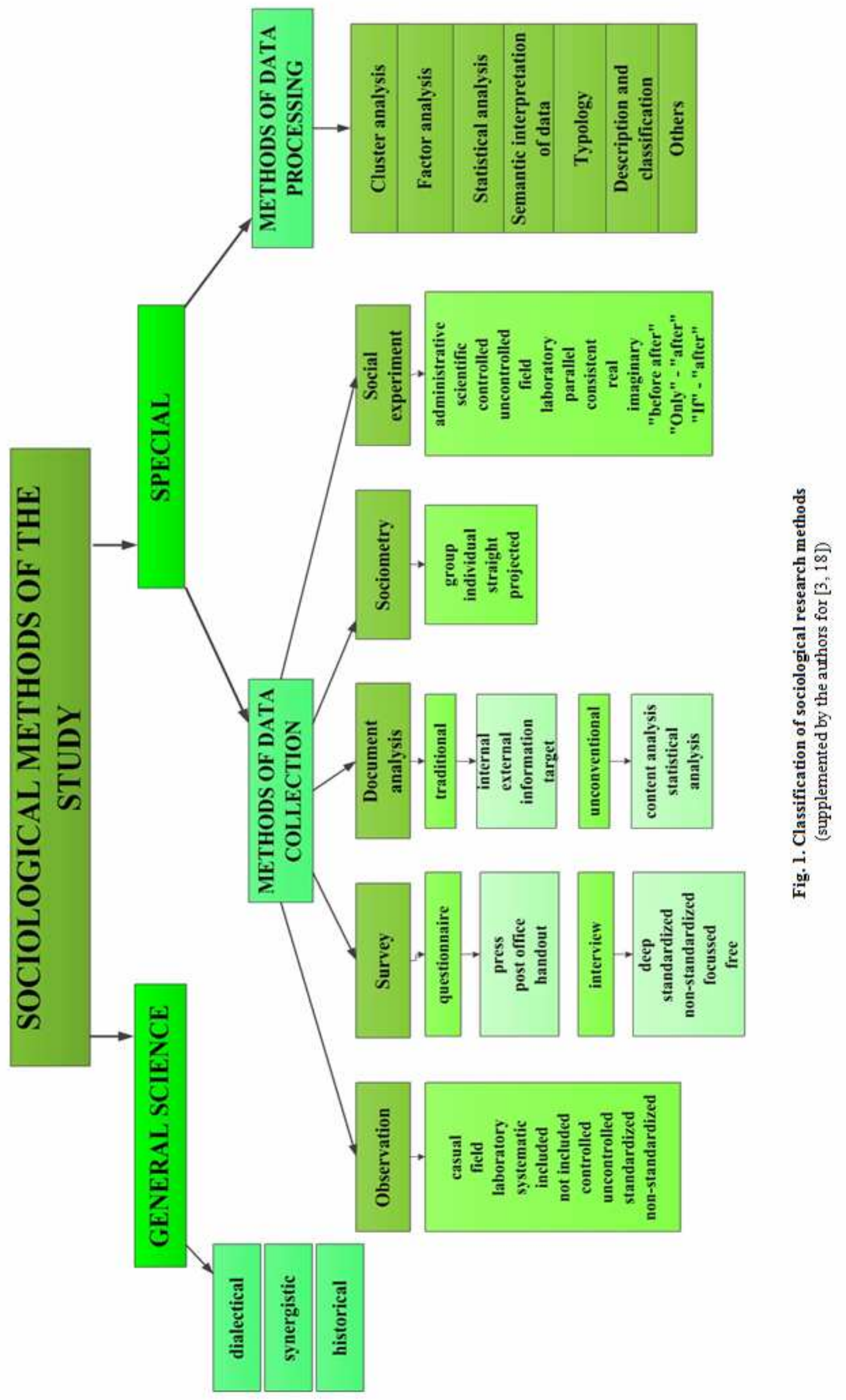




\begin{tabular}{|c|c|c|c|c|c|c|}
\hline \multirow{4}{*}{ 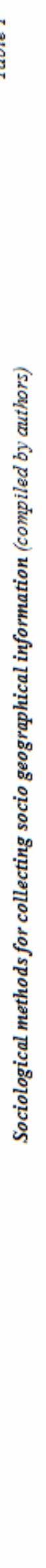 } & 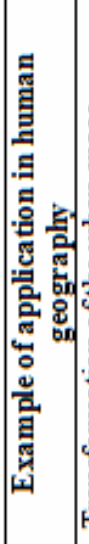 & 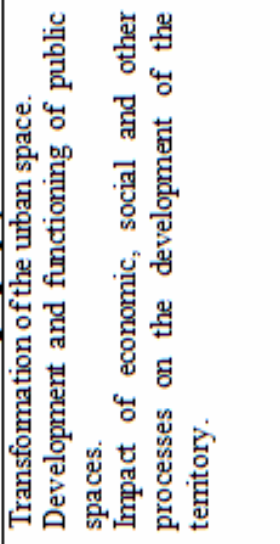 & 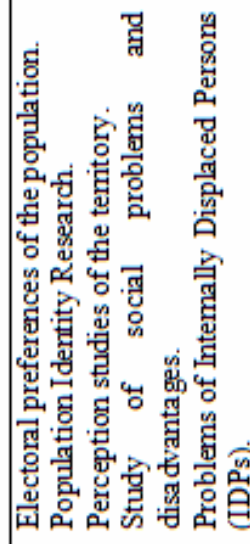 & 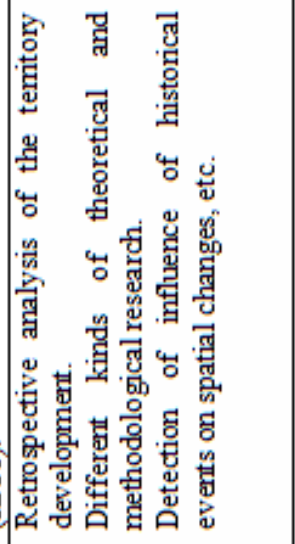 & 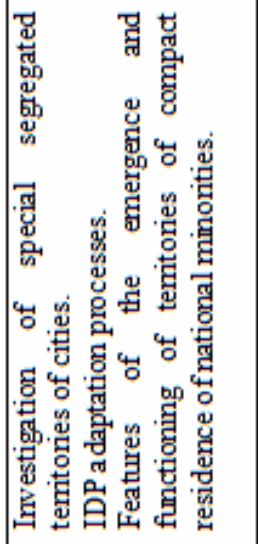 & 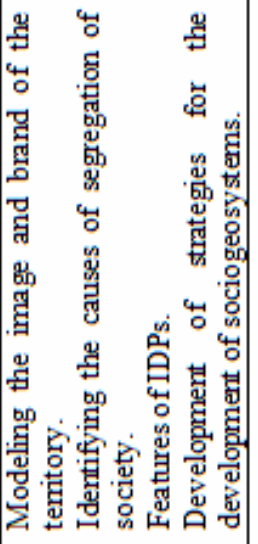 \\
\hline & 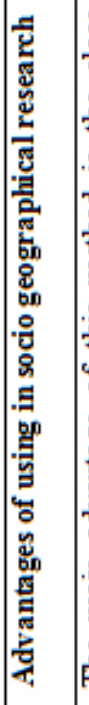 & 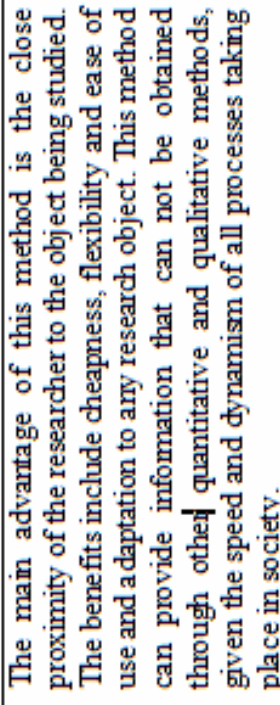 & 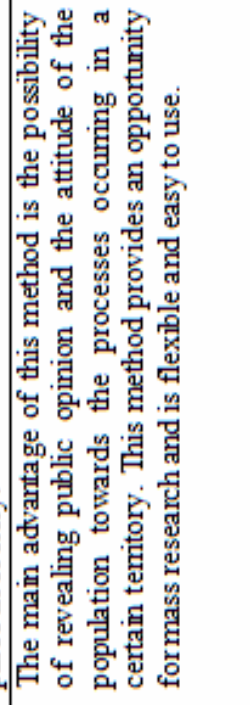 & 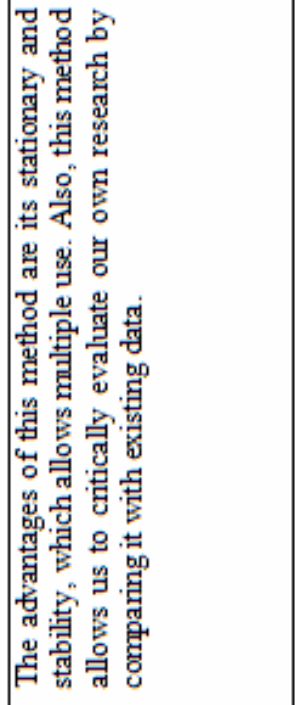 & 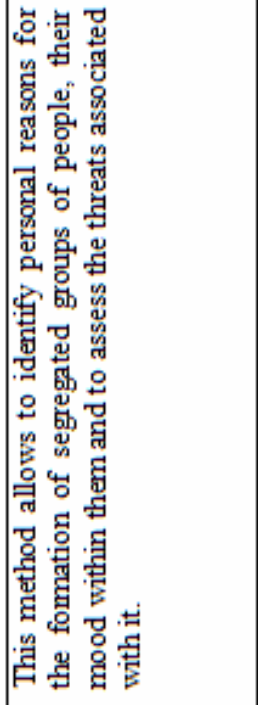 & 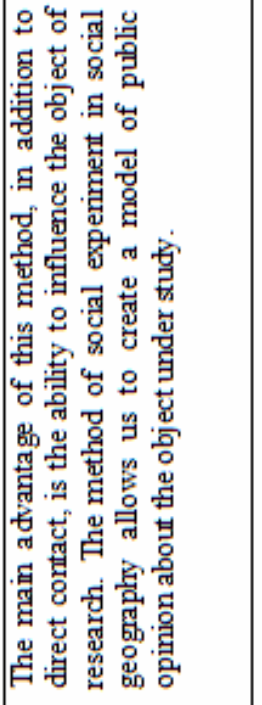 \\
\hline & 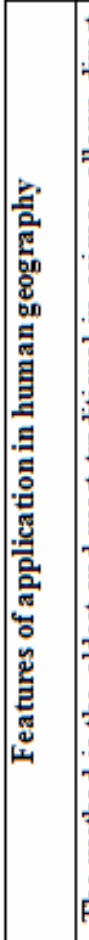 & 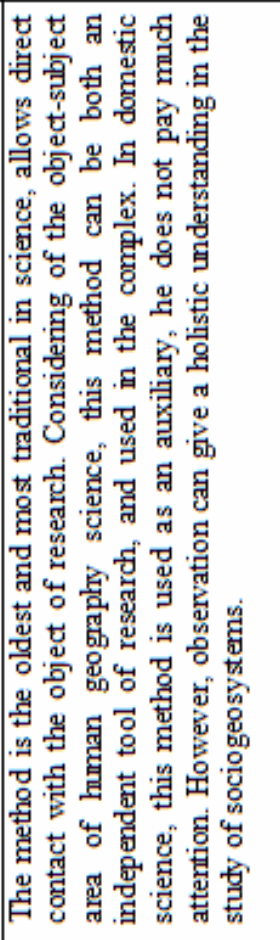 & 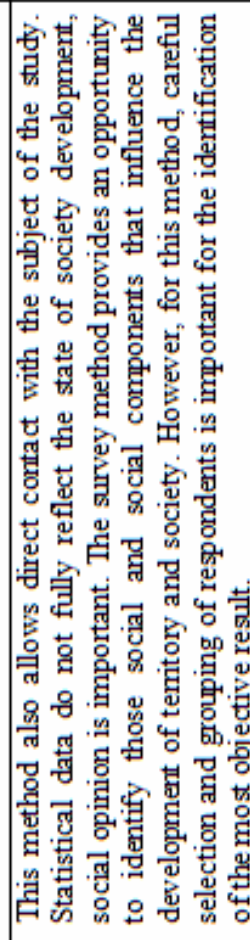 & 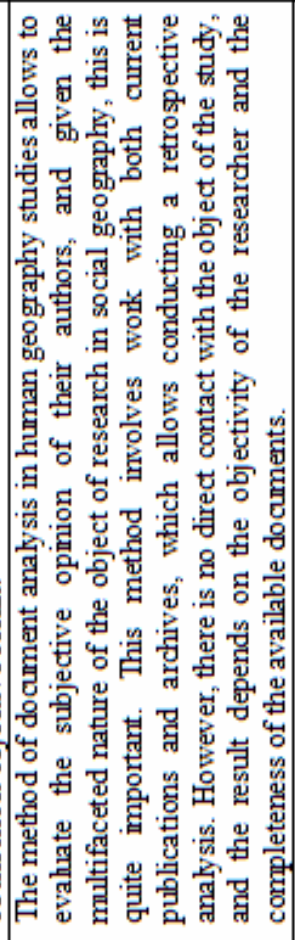 & 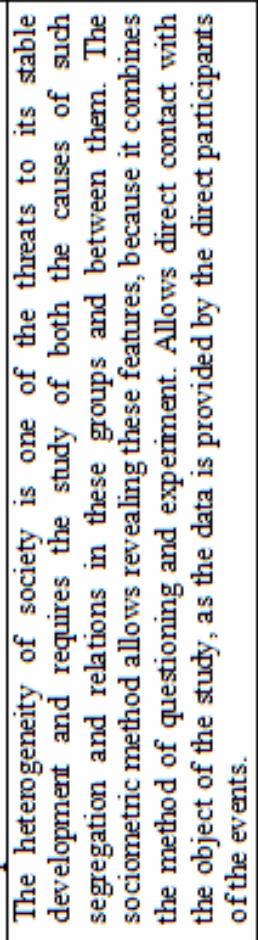 & 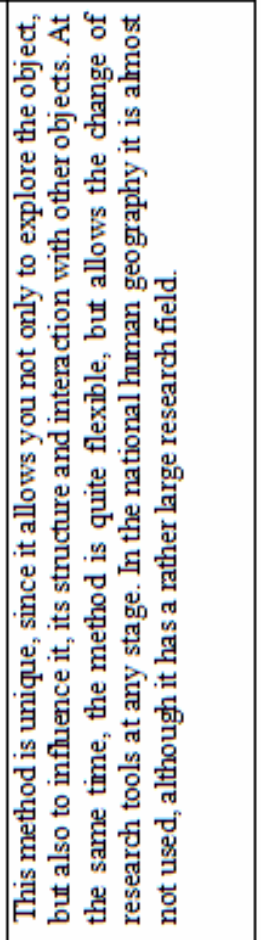 \\
\hline & 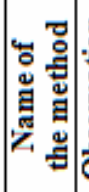 & & 竞 & 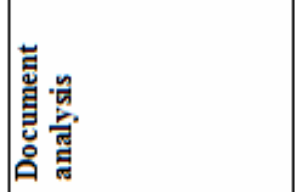 & & 兽 \\
\hline
\end{tabular}


Survey - receiving information in the course of socio-psychological interaction (direct or indirect) of the researcher and respondent in the question-appropriate form. The main types of survey are questionnaires and interviews, which, in turn, can be on-look (referral for questioning) or absenteeism (press, postal for questionnaires, telephone interviews). The interview may be: deep, standardized, non-standardized, focused, free. Survey is the most common method of gathering sociological information [11].

A sociological survey takes place in several stages:

1. The justification of the motivation for which the survey is conducted, the definition of the main goal and auxiliary tasks that allow achieving the goal.

2. Formation of the sample: it is necessary to follow a defined selection system of respondents in order to achieve the representativeness (representation) of data obtained during the survey.

3. Development of survey tools and their testing: one of the most important components of the sociological research is a well-designed survey tool - a questionnaire that needs to be tested before the collection of primary information, that is, to check the quality of the questionnaire itself and its ability to meet the goal of the study.

4. Collection of primary information: consists of selection and interviewing of interviewers, direct questioning. Interviews can be made by telephone, by house, on the street.

5. Encoding the results and processing them: encoding the results allows you to organize information, work with it and apply it. The coded information is subject to computer-mathematical processing.

6. Analysis of the results of the public opinion poll: based on the research conducted, conclusions, assumptions, and recommendations for solving a particular social problem in the form of a specific report [2] are made. In the future, other methods, such as simulation to justify ways to improve or change the situation, are used.

In this article, we focused on the advantages of using the method of interviews, document analysis and observation in human geographical studies. These methods are considered by the example of the IDPs in Ukraine, surveys (using various forms) can provide information on the structure of IDPs, their social and economic characteristics and their impact on the socioeconomic development of the territory, as well as possible options, their influence on the identity of the population of host regions.

The interview method in the IDPs study in Ukraine is characterized by a number of advantages compared with other methods of collecting information: carried out in a short time; representative; controllable; has the ability to combine with other methods of collecting information; may be immediate, since the researcher may be face to face with the respondent; combines simultaneously different forms of communication with the respondent; location of the interview may vary depending on the wishes of the respondent; allows you to obtain additional information and explanations from the respondent; has the ability to quickly change the content of the interview questionnaire.

Deep interviews are a personal interview of the interviewer with the respondent according to a predetermined plan and are widely used in sociogeographical research, but depending on the research objectives, they may differ in technique. The purpose of the deep interview is to identify the opinions, assessments, value orientations of the respondents and conduct without a pre-formed questionnaire. There is a structured "open", semi-structured and unstructured interview. All of these varieties can be applied depending on research objectives [27].

A structured "open" interview is a kind of qualitative interview and is usually used in expert surveys, as well as in adapting toolkits for mass surveys (at the design and implementation stage). In these interviews, all respondents are asked the same questions. The wording and sequence of questions are given rigidly. That is, during an interview it is impossible to change the place questions, reformulate them. This type of interview in human geographical research will allow not only to adapt the toolkit, but also to get an expert opinion on the issues of interest to the researcher in the first place.

The following questions can be formulated by conducting a structured "open" interview with the population regarding their relationship to internally displaced persons (tab. 2):

Example of a structured interview questionnaire (developed by the authors):

Table 2

Total information

\author{
1. Year of birth \\ 2. Indicate the name of the settlement, region and country where you were born \\ Locality \\ Region \\ A country \\ 3. What language do you mainly speak: \\ 1. Mostly Ukrainian \\ 2. Mostly, in Russian \\ 3. Mostly, on surzhik \\ 4. Russian and Ukrainian equally \\ 5. In another language / languages
}




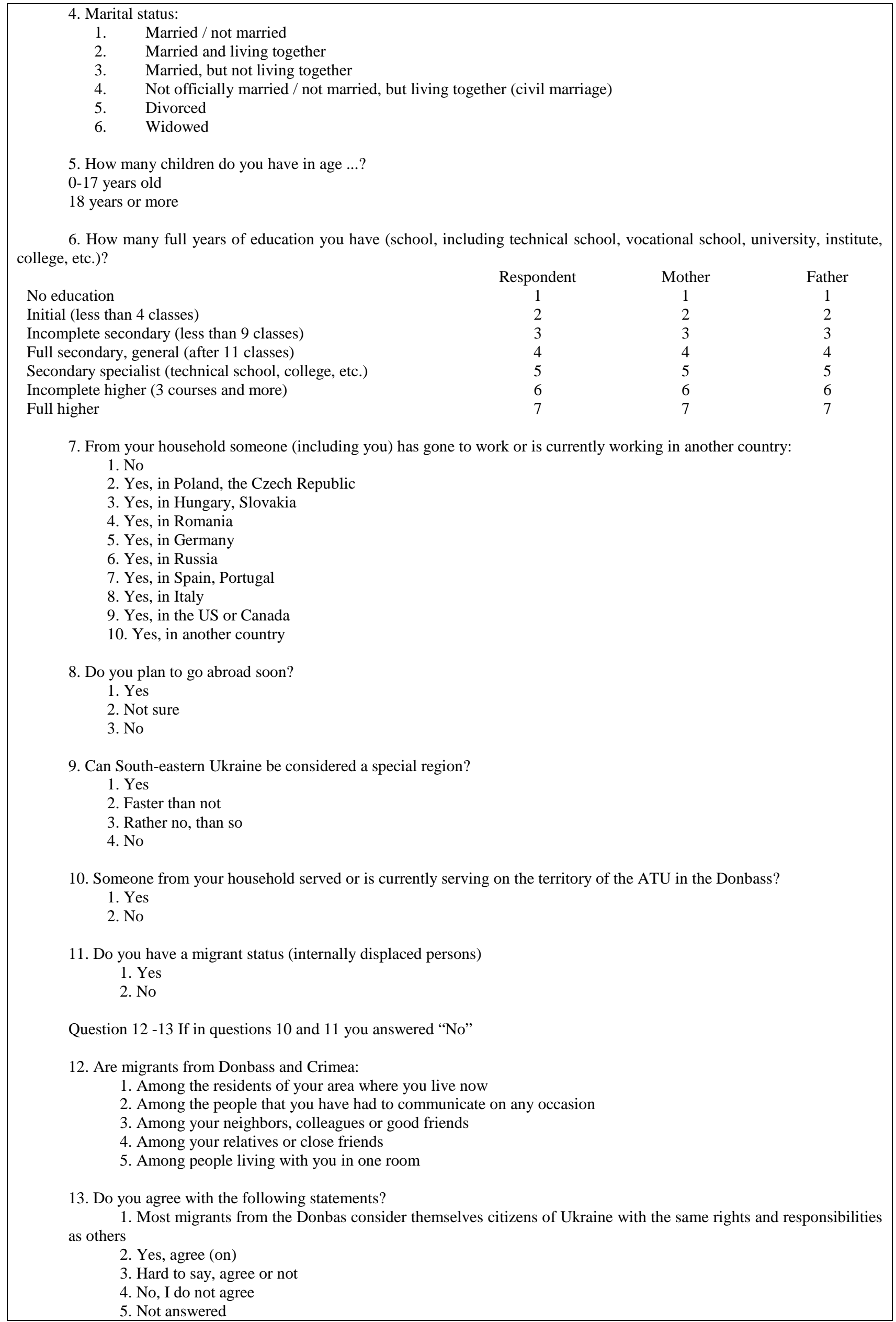


Semi-structured interviews are a kind of qualitative interview, which involves the presence of a certain prelist of topics (thematic blocks) that are of interest to the researcher. However, unlike structured "open" interviews, questions can be asked within the set themes. There is no need to adhere to a certain sequence of issues and even blocks of topics. It is important for each topic to be as open as possible [3].

An unstructured (free, narrative) interview is a free narrative on a given topic, in the process of which the speaker's memory inevitably emits episodes that are subjectively assessed by them as the most valuable, important, and, therefore, is a peculiar "point reference", a turning point in life. During the interview, only the clarifying questions are asked. Additional questions are asked, as a rule, after the end of the story. Narrative interviews can be used in studies, the subject of study of which are, for example, specific groups of people, internally displaced persons, and the subject - the sociopsychological characteristics of these groups of data or the decision-making process in a particular situation.

The method of focus group interviewing is used successfully to study the attitude of local people to internally displaced persons or internally displaced persons to local authorities and serves as a basis for social forecasting. Focus groups are used in the methodological provision of sociological research (hypothesis testing, flight instrumentation). Focus group interviews are based on the use of real group dynamics in an artificially created group to identify the specifics and peculiarities of representations of a particular social group about the subject of the study. Traditionally, the founder of this method is considered to be Robert Merton, whose work "Focused interview" (in collaboration with $M$. Fiske and P. Kendall) is recognized as classical [9]. Speaking about the use of focus groups in the field of IDPs, it should first be noted that the focus group can identify IDPS problems, a set of explanatory schemes that respondents describe their own behavior. It is important to have a self-explanatory description of their own motives and not a choice from the proposed list of possible alternatives.

Also, in social geographic studies, the document analysis of is used. This is a method of study in which the source of information is text messages, in any documents, reports, publications in newspapers, magazines, in letters, works of art, and illustrations.

First of all, the document analysis is carried out with the aim of studying the regulatory framework for the settlement of relations and the definition of the status of internally displaced persons; analysis of static materials to determine the quantitative characteristics of IDPs, peculiarities of their resettlement and integration, problems faced by immigrants themselves. This method defines both the personal characteristics of the migrants, their structural and dynamic features, and the peculiarities of the presentation of these characteristics by the media. This method is well suited for analyzing the migrants' histories, where researchers study or analyze socio-demographic characteristics of internally displaced persons.
In the complex of human geography researches for the collection of information can use the method of express-observation but its use depends on a number of features. This method is well suited for studying specific population groups, such as internally displaced persons who are not concentrated locally but live, for example, in places of compact residence of settlers. Using this method, we distinguish several types of social phenomena that can become objects of observation: individual psychological characteristics of the migrant or group of migrants, their interaction with other IDPs and the local population, problems that arise before internally displaced persons and hinder successful integration into host communities, etc.

Taking into account the following sociological methods of gathering information, it can be safely asserted that their application has a positive effect on solving many research issues in contemporary human geography researches.

Conclusions. The analysis of previous studies, including foreign ones, showed the importance of interdisciplinary research. In contemporary conditions, this applies, in particular, to the combination of sociological and geographical methods in human geography researches. This is especially true of the application of sociological methods for gathering information in contemporary human geography. The combination of these methods is extremely necessary, taking into account the transformation of the objectsubject area of human geography and insufficiency, and often the unreliability of the available statistical information for analyzing and highlighting the specific features of social change.

The great arsenal of sociological methods makes it possible for a researcher to make a wide choice. However, the role of sociological methods of collecting information in studies of human geography is positive only when the research itself is aimed at obtaining an objective picture of the events studied or help fix the true features and causes of a particular social situation. Otherwise, the consequences of their use in society may be unpredictable. In general, sociological methods in human geography make it possible to identify the specific characteristics of socio-geographical objects, phenomena and processes that can not be investigated by traditional geographic methods, as well as by processing only statistical information.

We have considered the application of sociological methods for collecting information when studying internally displaced persons in Ukraine. This problem is very acute in Ukraine and requires an urgent solution, and hence research. Quantitative and qualitative methods used in studies IDPs, have their own peculiarities, primarily related to the peculiarity of the phenomenon under investigation. The behavior of IDPs, their problems and the particularities of coexistence with the local population allows researchers to choose strategies and methods that are most appropriate and correlate with methodological and methodological settings, the purpose and objectives of the study.

Consequently, these sociological methods of collecting information require extensive testing in human 
geography researches, which is one of the tasks of the transformation of the methodological apparatus of science. However, solving complex problems of human geography researches, only on the basis of one method is impossible. Therefore, it is necessary to use a combination, a combination of different methods, that is, to create a research methodology that accumulates different approaches and determines the order (sequence) of their application. The peculiarities of the use of sociological methods, in particular, the methods of collecting information in the human geography, require further scientific research, discussion in the scientific environment. In addition, in further socio-geographical research authors plan to justify the use of other sociological methods: methods of processing, analysis and interpretation of data.

\section{References:}

1. Andrushchenko, V.P., \& Horlah, M. I. (1998). Sotsiologiya [Sociology]. Kharkiv, Kyiv, 597-616 [in Ukrainian].

2. Bekeshkina, I. (2006). Sotsiologichni opytuvannya: yak yikh provodyty, tlumachyty i vykorystovuvaty? [Sociological polls: how to conduct, interpret and use them?]. Posibnyk z pytan rozvytku publichnoi polityky dlya ekspertiv neuryadovykh organizatsiy - A guide on the development of public policy for experts of non-governmental organizations, 35-40 [in Ukrainian].

3. Verbets, V.V. (2006). Metodologiya ta metodyka sotsiologichnykh doslidzhen: navchalno-metodychnyi posibnyk [Methodology and technique of sociological research: teaching aid]. Rivne: RDHU: Instytut sotsialnykh doslidzhen, 167 [in Ukrainian].

4. Zdravomyslov, A.G. (1969). Metodologiya i protsedury sotsiologicheskikh issledovaniy [Methodology and procedures of sociological research]. Moskva, Mysl, 205 [in Russian].

5. Korobov, V.K., Liapina, L.A., Ortseva, O.S. and etc. (2016). Sotsiologichni doslidzhennya problem evrointegratsii ta evropeyskykh studiy v Ukraini [Sociological studies of European integration and European studios in Ukraine]. Mykolaiv: Vyd-vo ChDU imeni Petra Mohyly, Vol. 241, 68 [in Ukrainian].

6. Kraus, N.M. (2012). Metodologiya ta organizatsiya naukovykh doslidzhen [Methodology and organization of scientific research]. Poltava: Oriyana, 183 [in Ukrainian].

7. Liubyva, T., \& Nikitina, T. (2013). Predstavlennya rezultativ analizu danykh kilkisnykh sotsiologichnykh doslidzhen u naukovykh publikatsiyakh [Presentation of the results of the analysis of kilkish sociological data on scientific publications]. Sotsialni vymiry suspilstva - Social dimensions of society, 5(16), 763-779 [in Ukrainian].

8. Manak, B.A. (1985). Metodika ekonomiko-geograficheskikh issledovaniy: uchebnoe posobie [Technique of economic-geographical research: Tutorial]. Minsk: Universitetskoe, 157 [in Russian].

9. Merton, R., Fyske, M., \& Kendall, P. (1991). Fokusirovannoe intervyu [Focused interview]. Moskva: Institut molodezhy, 106 [in Russian].

10. Myrosh, M.V. (2014). Metodyka suspilno-geografichnoho doslidzhennya politychnoi aktyvnosti naselennya regionu [Methods of human geography studues of the political activity of the population of the region]. Visnyk Odeskoho natsionalnoho universytetu. Geografichni ta geologichni nauky - Odesa National University Herald. Geography and Geology, 19(4), 188-197 [in Ukrainian].

11. Mikhayleva, E.G. (2016). Metodologiya i metody sotsiologicheskikh issledovaniy [Methodology and methods of sociological research]. Kharkov: NUA, 286 [in Russian].

12. Niemets, K.A., \& Niemets, L.M. (2014). Teoriya i metodologiya geohrafichnoi nauky: metody prostorovoho analizu [Theory and methodology of geography: spatial analysis methods]. Kharkiv: KhNU imeni V.N. Karazina, 172 [in Ukrainian].

13. Niemets, K. (2006). Suspilna geografiya: problemy i novi horyzonty [Human geography: problems and new horizons]. Chasopys sotsialno-ekonomichnoi geografii - Human Geography Journal, 1, 60-69 [in Ukrainian].

14. Niemets, L., \& Mezentsev, K. (2019). Sotsialna geografiya [Social geography]. Kyiv: Feniks, 304 [in Ukrainian].

15. Niemets, L. (2006). Teoretyko-metodolohichni aspekty suchasnoi sotsialnoi geografii [Theoretical and methodological aspects of modern social geography]. Chasopys sotsialno-ekonomichnoi geografii - Human Geography Journal, 1, 45-55 [in Ukrainian].

16. Oliynyk, Ya., \& Stepanenko, A. (2006). Metodologichni pryntsypy doslidzhen v ekonomichniy i sotsialniy geografii [Methodological principles of research in economic and social geography]. Chasopys sotsialno-ekonomichnoi geografii - Human Geography Journal, 1, 6-21 [in Ukrainian].

17. Palchuk, M.V. (2018). Publichni prostory mista Kyeva: suspilno-geografichne doslidzhennya [Public spaces of the city of Kiev: a human geography study]. Candidate's thesis. Kyiv, 247 [in Ukrainian].

18. Panina, N.V. (2007). Tekhnologiya sotsiologichnoho doslidzhennia [Technology of sociological research]. Kyiv: Instytut sotsiologii NANU, 320 [in Ukrainian].

19. Savchenko, I.A., \& Shevchuk, O.A. (2014). Osnovy metodyky suspilno-geografichnoho doslidzhennya terytorialnopolitychnoi systemy region [Fundamentals of the method of socio-geographical study of the territorial-political system of the region]. Naukovi zapysky Ternopilskoho natsionalnoho pedahohichnoho universytetu imeni Volodymyra Hnatiuka. Seriya: Geografiya - The scientific issues of Ternopil Volodymyr Hnatiuk national pedagogical university. Series: Geography, 2, 69-76 [in Ukrainian].

20. Salyuk, M.R. (2016). Metodychni materialy do vykonannya praktychnykh robit z kursu Metody heohrafichnykh doslidzhen [Methodical materials for the implementation of practical work on the course "Methods of geographical research"]. Uzhhorod: "UzhNU”, 38 [in Ukrainian]. 
21. Topchiyev, O.H. (2005). Suspilno-geografichni doslidzhennya: metodologiya, metody, metodyky [Human geography researches: methodology, methods, techniques]. Odesa: Astroprynt, 631 [in Ukrainian].

22. Kharchenko, O.I. (2011). Porivnyalna kharakterystyka metodologichnykh pidkhodiv u sotsiologichnykh doslidzhennyakh [Comparative characteristics of methodological approaches in sociological research]. Aktualni problemy sotsiologii, psykhologii, pedagogiky - Actual problems of sociology, psychology, pedagogy, 13, 103-110 [in Ukrainian].

23. Shabliy, O.I. (2012). Osnovy suspilnoi geografii [Basics of Human Geography]. Lviv: LNU imeni Ivana Franka, 296 [in Ukrainian].

24. Shabliy, O.I. (2001). Suspilna geografiya: teoriya, istoriya, ukrainoznavchi studii [Human geography: theory, history, ukrainian knowledge]. Lviv: LNU im. I. Franka, 744 [in Ukrainian].

25. Baxter, J., \& Eyles, J. (1997). Evaluating qualitative research in social geography: Establishing "Rigor" in interview analysis. Transactions of the Institute of British Geographers, 22, 505-525.

26. Clark, G.L. (1998). Stylized facts and close dialogue: methodology in economic geography. Annals of the Association of American Geographers, 88, 73-87.

27. Flowerdew, R., \& Martin, D. (2005). Methods in human geography: a guide for students doing a research project. Harlow: Pearson, 366.

28. Harvey, D. (2006). The Sociological and Geographical Imaginations. International journal of Politics, Culture and Society, 18, 211-255. Retrieved from: http://www.urbanlab.org/articles/Harvey\%20soc\%20geo\%20imagination.pdf.

29. Hurst, M.E. (1985). Geography has neither existence nor future. The Future of Geography, 59-91 [in English].

30. Ley, D. (1988). Interpretive social research in the inner city. Research in human geography, 121-138 [in English].

31. Philip, L.J. (1998). Integrating Quantitative and Qualitative Approaches to Social Research in Human Geography an Impossible Mixture? Environment and Planning A, 30(2), 261-276.

32. Stuart, A., \& Gill, V. (2006). Approaches to Human Geography. SAGE Publications Ltd, 360.

Надійшла до редколегї 05.04.2019 p.

\section{Про авторів:}

Людмила Нємець - доктор географічних наук, професор, завідувач кафедри соціально-економічної географії і регіонознавства, Харківський національний університет імені В.Н. Каразіна, Україна,

ludmila.nemets@karazin.ua, https://orcid.org/0000-0001-9943-384X

Марина Логвинова - аспірант кафедри соціально-економічної географії і регіонознавства, Харківський національний університет імені В.Н. Каразіна, Україна,

logvinova_mari94@ukr.net, https://orcid.org/0000-0003-3190-710X

Ольга Суптело - аспірант кафедри соціально-економічної географії і регіонознавства, Харківський національний університет імені В.Н. Каразіна, Україна,

syptelo@gmail.com, https://orcid.org/0000-0003-2901-8565

\section{Об авторах:}

Людмила Немец - доктор географических наук, профессор, заведующая кафедрой социальноэкономической географии и регионоведения, Харьковский национальный университет имени В.Н. Каразина, Украина, ludmila.nemets@ karazin.ua, https://orcid.org/0000-0001-9943-384X

Марина Логвинова - аспирант кафедры социально-экономической географии и регионоведения, Харьковский национальный университет имени В.Н. Каразина, Украина, logvinova_mari94@ukr.net, https://orcid.org/0000-0003-3190-710X

Ольга Суптело - аспирант кафедры социально-экономической географии и регионоведения, Харьковский национальный университет имени В.Н. Каразина, Украина, syptelo@gmail.com, https://orcid.org/0000-0003-2901-8565 